Volume 7, Issue 3, 667 - 677.

ISSN: $2165-8714$

http://www.eu-jer.com/

\title{
Opinions and Suggestions of Teacher Candidates on the Teaching of the Reading Skill in French Language: The Example of Uludag University
}

\author{
Erdogan Kartal * \\ Uludag University, TURKEY
}

Received: July 4, 2018 - Revised: July 13, 2018 - Accepted: July 16, 2018

\begin{abstract}
In this work, we have analyzed the opinions of teacher candidates of French as a foreign language on the method that should be used in the teaching of reading-comprehension, one of the main linguistic skills. At the end of the Fall Semester of the 2011-2012 academic year, a survey constituted of three open-ended questions was carried out among teacher candidates studying at the French Language Teaching Programme of the Faculty of Education of Uludag University. Among the 120 students enrolled in the Programme, 64 have participated in the survey voluntarily and expressed their opinions. Students have been priorly informed about the study and the link of the survey prepared via Google Docs has been sent to them through an e-mail where they were asked to fill in the study in Turkish. In the scope of the present work, only student opinions relating to option b of the study's second question -i.e. on the method that should be used in the teaching of the reading skill in French- have been taken into consideration. In this qualitative work based on a case study pattern, opinions have first been sorted out through the content analysis method and have been classified; then, they have been compared with and discussed in the light of opinions and suggestions that already exist in literature. Lastly, findings have been interpreted and presented as a determination.
\end{abstract}

Keywords: Teacher candidates of French, reading-comprehension skill, student opinions, content analysis.

To cite this article: Kartal, E. (2018). Opinions and suggestions of teacher candidates on the teaching of the reading skill in French language: The example of Uludag University. European Journal of Educational Research, 7(3), 667-677. doi: 10.12973/eu-jer.7.3.667

\section{Introduction}

Reading is one of the four fundamental skills that lay the ground for the learning/teaching processes of foreign language. This basic linguistic skill -also sometimes referred to as "written comprehension" in the area of foreign language teaching- is, according to Durmuscelebi (2009), a prerequisite for the individual's written and/or oral comprehension skills, and it also plays a significant role in the development of basic expression skills such as writing and speaking. A great number of definition have been made in literature with regards to the reading skill. For example, while Eriskon-Cangil (2008) defines "reading" as an activity where the individual conducts a relationship with symbols and makes sense of them, Akyol (2006) defines it as a process where foreknowledge is used and sense is constructed in an organized climate, based on an effective communication between the writer and the reader, with a proper method and in view of a purpose. Odabas, Odabas and Polat (2008) assert that reading is a holistic (global) process constituted of the stages of perception, sense-making, interpretation, thought and deduction by sensory organs of written messages created in line with grammar rules. Again, similarly, Gocer (2007) defines reading as the perception through senses, the understanding, the identification, the interpretation, the pondering upon and the deduction of texts written in accordance with linguistic rules. When we assess these definitions, we notice that they converge on the dimension of the reading skill based on the sense-making or sense construction / interpretation of what is read (Pekkanli and Kartal, 2010).

In general, we observe that these definitions made for the reading skill in the mother tongue are also valid for the reading skill in the second/foreign language. So much so that, according to Boyer, Butzbach-Rivera and Pendanx (1990) and Benito (2003), all concepts, theories and approaches that have been emerging since the 70s' have been influenced by studies conducted on the reading skill in the mother tongue. In fact, Benito (2003) argues that Goodman's article Reading a Psycholinguistic Guessing Game (1967) which became a classic and which explains his hypothesis on the physical and cognitive processes (phases) of reading is the main foundation for all the studies in question. On the other hand, Cameron (2005) states that one of the factors influencing the reading skill in the foreign language is the reading experience in the mother tongue, and when one is introduced to a new language, the brain automatically searches for

\footnotetext{
* Correspondence:

Erdogan Kartal, Uludag University, Faculty of Education, Department of Foreign Languages, French Language Teaching Programme, Bursa, Turkey. Email: ekartal@uludag.edu.tr
} 
similar clues and tries to apply the mother tongue experience. Similarly, Lee and Schallert (1997) put forth that a reader who is flexible, adaptative, inquisitive and controlling of one's perception will have higher chances at having those same characteristics when reading in a foreign language; thus, the reading skill in the mother tongue becomes an influencing factor in the development of the reading skill in the second/foreign language.

When the role and significance of the reading skill in the methods and approaches developed for the teaching of a foreign language to date is handled from a historical point of view, we observe that, compared to other linguistic skills, this one has been largely neglected; especially in the last century. As a matter of fact, the "traditional method" -also called the "translation-grammar" method- was nearly the sole valid method adopted and used worldwide in the teaching of a foreign language until the beginning of the 20 $0^{\text {th }}$ Century. Although the act of translation is the main component of the essence of this method, one of its main goals was to raise students who could read and understand literary texts in the target (foreign) language and write in that language (Besse, 1985). Along with writing, the reading skill had a privileged place in this traditional method. However, in the first quarter of the $20^{\text {th }}$ Century, the "direct method" -which prioritized the speaking skill- and its offsprings -the "hear-speak" and "audiovisual" techniques elaborated in parallel with technological, cognitive and linguistic developments- nearly totally ignored this skill, particularly in their wake (Bertocchini and Costanzo, 1989; Tagliante, 1994). On the other hand, the notion of "authentic" that came to prominence with the "communicative approach" at the beginning of the 80s' ensured the reading skill regains the value it deserved. Course books designed in light of this approach have been enriched with culture and literary-themed authentic up-to-date texts in order to equip students with a genuine reading skill right from the beginning (Kartal, 1999). In the wake of the new millennium, the communicative approach has been gradually replaced by the "action-oriented approach", which was a new language teaching approach adopted with the establishment of the Common European Framework of Reference for Languages (2001). The action-oriented approach suggests the focus on the tasks to be carried out in the scope of a common project; thus, in this context, the action reveals the interaction destined to the development of perceptive (understanding what is listened to and read) and interactive skills (speaking and writing to someone). According to this approach, whoever learns a language uses it to carry out a task. In this context, reading is also from there on action-oriented, just like the other skills. Hence, it exists to make something (by wielding language) and thus, has equal priority with other main linguistic skills (Coskun, 2017).

In the process of foreign language teaching, particularly of French as a foreign language, when it comes to the way this fundamental linguistic skill must be taught to students, we see that, especially in the communicative approach emerging from the end of the 70s' to the beginning of the 90s', leading scholars of French as a foreign language such as Coste (1978), Vigner (1979), Moirand (1979), Lehmann and Moirand (1980), Besse (1984), Achard-Bayle (1984), Gaonac'h, (1990), Dévelotte, (1990), Deschênes (1991), Cicurel (1991) and Beacco (1991) have been focusing on this matter directly and have created numerous theoretical and practical monographic works. In the following years, we observe that all of these works have also paved the way for similar studies in the same area (Lavaur, 1995; Vigner, 1996; López Alonso and Seré de Olmos, 1996; Adam, 1997; Lassoff-Delahousse, 1997; Gaonac'h, 2000; Rui 2000; Souchon, 2000; Boucher, 2002; Van Chuong, 2003; Benito, 2003; Gunday 2010; Boustane-Boubir, 2010; Kunze, 2012; González Hernández, 2012; Rodríguez Pedreira, 2013).

Nevertheless, when we take a close look at the studies in question, we observe that they are rather theoretical works based on teachers' years-long experiences and observations in the classroom. But then, how should this linguistic skill be taught according to the student who is nowadays defined as the "actor" (Conseil de l'Europe, 2001) by the actionoriented approach, and who is put at the center and prioritized by the (learner-centred) communicative approach (Galisson, 1980)? Because for Pallotti (2002), the language class in any educative institution is a communicative space where an interactive communication network (teacher-student) is created, rather than being just a physical environment. Here (in classrooms), all rules regarding communication are generally predetermined by the relevant institutions in the framework of certain protocols. Actually, these are routine rituals such as greetings by the teachers at the beginning and end of the lesson, directives given by the teacher during lesson and rules which students must follow. In this contract called "Educational Agreement" (Le contrat didactique) what, how, how much and how long the student must learn is in reality left obscure and the student is generally not aware of this aspect. Therefore, in order to create a cooperative awareness such as is deemed necessary by the agreement, parties (students and teachers) must discuss, accept and share a new version of this contract by redefining and clarifying it as a "Learning Agreement" (Le contrat d'apprentissage) instead. Weiss (1979) argues that students' linguistic needs must be taken into consideration during the language teaching process. From that perspective, one could argue that students too should have a say in the methods through which fundamental linguistic skills should be taught them.

In other respects, when we take a look at two of the most widespread national and international online academic browsing platforms such as the Higher Education Academic Browsing portal (http://akademik.yok.gov.tr/AkademikArama/) and Google Scholar (https://scholar.google.com/), we notice an increase in researches on students' opinions on language teacher education in recent years based on separate simple searches made with the key words "student opinions" both in Turkish and in English, especially in the field of teacher education in the last few years, suggesting the creation of a research tradition in that area. 


\section{Purpose of the Study}

In this study, we aim at analyzing the opinions of teacher candidates of French on the methods with which the reading skill -one of the fundamental linguistic skills- in the teaching of French as a foreign language should be taught.

\section{Method}

This study has adopted a qualitative approach and has been structured in line with the case study pattern. According to Basturk (2011), measurements can make us understand the number of people behaving in a certain way; however, they cannot answer the "why" of that behaviour. The reason of human and group behaviours can only be clarified via qualitative researches. The main aim of these types of researches is to present a descriptive and realistic picture of the subject of study, rather than to reach out for results that are generalizable with numbers, as is the case in quantitative researches. Since the present study is not intended for generalization purposes, the findings are only limited to teacher candidates participating in the study. As for the case study pattern, it is a research modeling which allows for an indepth analysis of any given phenomenon in its natural environment (Yildirim and Simsek, 2011). Given that in this study, only one analysis unit is intended (namely, the in-depth analysis of opinions of students -or teacher candidatesof Uludag University Faculty of Education French Language Programme on how one of the fundamental linguistic skills, reading, should be taught in the teaching process of French as a foreign language), the present work has been realized based on a single-case holistic pattern.

\section{Participants}

The present study has been carried out with the participation of 64 volunteers of all undergraduate level students among 120 students enrolled in the French Teaching Programme of Bursa Uludag University, Faculty of Education, during the Fall Semester of the 2011-2012 academic year. All participants had been taken at least one year of French lessons in preparation school before starting their undergraduate studies at their Programme, most of them having graduated from secondary education institutions focusing on foreign language (English), and thus already having a certain idea of foreign language. On the other hand, according to Yildirim and Simsek (2011), since accessibility is one of the factors to be taken into consideration when determining the sample in qualitative studies, the study group in the present work has been determined according to the convenience sampling method among purposive sampling methods. This sampling method is, according to Piji Kucuk (2014), a low-cost method which adds speed and practicability to such studies.

\section{Data Collection Tool}

The study's data have been collected via the following survey constituted of three half-structured open-ended questions created by the author:

According to you: 1. Which techniques and methods should be used inside and outside the classroom for an efficient teaching of French as a foreign language? 2. How should the four linguistic skills, i.e. a) speaking, b) reading, c) writing, d) listening, be taught in the process of teaching French as a foreign language? 3. What type of assessment-evaluation technique(s) (i.e. exams) should be used in the process of teaching French as a foreign language and how should they look?

The link of the survey prepared via Google docs has been sent through the UKEY's (Uludag University Institutional, Educational and Research Governance System) "send message to students" option during semester to students who had been priorly informed about the study during classes (2011-2012 Fall). Also, it has been emphasized that the feedbacks to be given by students as teacher candidates were very important for the improvement and restructuration of the teacher education programme, therefore students were asked to express their opinions in Turkish.

Students were asked not to give any identity information to make sure that the assessment to be made be as natural as possible. For Oppenheim (1992), in open-ended surveys there are limitations such as the giving of irrelevant answers, the time that analyses take, the requirement for technical skills for analyses and the duration of the answering process influencing the answering rate. However, despite these challenges, Brew (2008) argues that open-ended surveys give participants the possibility to express their opinions as freely as possible and hence, allow them to fully reflect their perspectives. That is why this type of surveys are preferable.

As part of the study, only student opinions expressed in the second part (part b: on the way the reading skill should be taught) of the second question of the survey given above has been taken into consideration. All studies carried out on the remaining questions and subquestions have previously been presented by the author in international conferences (Kartal and Parlak, 2016a; 2016b; 2017; Kartal and Alpar, 2017a; 2017b), and some of these have been published in full text as articles in international journals (Kartal and Parlak, 2017) and chapters in books (Kartal and Parlak, 2018).

\section{Data Analysis}

The link of the survey with open-ended questions created on 30.10.2011 on Google Docs has been sent to students via e-mail. 64 volunteering students have activated the link in a period of 17 days until 17.11.2011 and reached the survey, 
answering each question and saving their answers. The author reached those answers via his Google account and downloaded them to his computer as an e-table in Excel format. Then, all answers given to each question and its subparts have been transferred to Word documents separately and been saved. Answers given by students have been marked with the abbreviation "S" ("Student") and have been numbered from 1 to 64 as "S1" and "S64".

Data have been analyzed with the content analysis method which is one of the qualitative methods. In content analysis which consists of a systematic and renewable technique (Buyukozturk et al. 2012) where certain words of a text are summarized with smaller categories through codings based on certain rules, the main goal is to define data and to unveil truths that may be hidden in them (Yildirim and Simsek, 2011).

With this perspective in mind, the author got together with a specialist on the field and came to an agreement on what the main categories could be after students' answers would be analyzed in a general fashion. Then, the two researchers went on to code the data separately and classified them under the priorly agreed-upon categories. Since teacher candidates' opinions had been collected through an open-ended survey, as can be seen in the two examples given below, when expressing their points of view, students either state only one opinion in one sentence or paragraph, or, they express several.

[S33]: "I believe it would be helpful if we did more reading aloud in the classroom. The teacher should tell students that it's ok if they make mistakes when reading, and that they should not be afraid because of that [How should class be conducted?]. Because the more reading will be done, the more progress will be made. The student will realize with time that they read faster and make less mistakes while doing so. The teacher should enable them to make this exercise."

[S39]: "Reading exercises conducted on texts in the target language [How should class be conducted?] and prepared in accordance with the student's capacity and socio-economic background [What should be read in class?] could be done. The teacher should know their students and choose texts whose subjects [What should be read in class?] might draw their attention. French classics [What should be read in class?] could be used for improving the reading skill. The titles and number of books to be read during semester could be determined jointly by the class, and periodical brain storming could be done in the following weeks on books that have been read by all. While reading continues, questions that might arise in students' minds, as well as proverbs and sayings they cannot understand could be discussed [How should class be conducted?].

The percentage of convergence between encoders has been calculated with Miles and Huberman's (1994) formula: reliability $=$ convergence of opinions / convergence of opinions + divergence of opinions $x 100$. In case the percentage of convergence is equal to or above $70 \%$ after calculation with the formula in question, reliability of data analysis is ensured. In this work, convergence between encoders has been calculated at $92 \%$. On the other hand, the totality of data gathered during research has been archived for the disposal of other researchers who might want to refer to them.

\section{Findings}

After analysis of the opinions expressed by the 64 participants of the study on how the reading skill should be taught in the teaching of French, 129 opinions have been stated and these have been classified under 5 main categories. These categories and the number of opinions each contain have been given in the table below (Table 1).

Table 1: Opinions of teacher candidates of French on the teaching of the reading skill

\begin{tabular}{lll}
\hline & \multicolumn{1}{c}{ Student Opinions } & $\mathrm{f}$ \\
\hline 1. & Opinions on types of texts to be treated / read during the reading course & 45 \\
\hline 2. & Opinions on the way the reading course should be conducted & 34 \\
\hline 3. & Opinions on this skill's relationship with other linguistic skills and objectives & 20 \\
\hline 4. & Opinions on what should also be done outside of class & 15 \\
\hline 5. & Opinions on the nature of the reading skill & 5 \\
\hline
\end{tabular}

According to Yildirim and Simsek (2011), the validity and reliability of findings in qualitative studies can be ensured through an utmost detailed and direct presentation of the collected data. With this approach, while findings have been given below under each category in order to ensure that research is reliable and findings are understandable, some of teacher candidates' answers have been quoted. Furthermore, as has been previously stressed, since generalization is not a concern in the presentation of findings in this study, each opinion has been included, even if it has been expressed by only one candidate.

\section{Opinions on types of texts to be treated / read during the reading course}

In this first category where more than $2 / 3^{\text {rd }}(\mathrm{f}=45)$ of participating teacher candidates have expressed their opinions, findings that were gathered after analysis of the types of texts to be treated / read during the reading course are presented. 
In this category, we observe that student opinions are gathered in two different groups. Candidates in the first group state that class could be started with simple and short stories [S14, S35 and S57], then, novels (French classics) tales and poems could be used [S15, S17, S26, S39, S37, S47 and S51].

As for candidates in the other category, instead of long and boring literary texts [S21], texts ranging from simple to hard [S13], from daily -"daily" as texts telling of subjects with which students are already familiar- [S34] to literary, and that are attention-grabbing could be used. Once again, texts that are not long and boring [S07 and S10], that are excerpted from French daily papers and magazines -such as articles, news, dialogues, caricatures, comics or easily-readable contemporary novels and tales- could be read during class S01, S05, S14, S18, S20, S29, S30, S39, S41, S44, S50, S48, S50, S54, S56 and S61]. Hence, the types of texts in question would be more understandable since they would include subjects students know about [S04]. As a consequence, not only the student's vocabulary [S32] would deepen while reading, but also, a faster and more efficient reading process could take place [S44].

Lastly, all candidates mentioned that all of the texts or books to be selected either by the student or by the teacher should match students' language level [S05, S06, S07, S12, S25, S36, S37, S39, S41, S42 and S50].

\section{Opinions on the way the reading course should be conducted}

More than half of teacher candidates who participated in the survey ( $\mathrm{f}=34$ ) have expressed a number of activities, approaches and suggestions on the way the reading skill course should be conducted. These comprehend the foundation of a reading infrastructure, the determination of a strategy, the establishment of an analysis method, the determination of in-class activities and the setting of priorities for students.

For candidates, the teacher of this course should first and foremost ensure their students have a sound reading infrastructure and a strategy on how they should read [S25]. During class, students should be encouraged to actively participate [S30 and S31], and texts that are selected should be scrutinized in detail with text examination and analysis methods [S06, S19, S24, S27, S29, S34, S45, S46 and S50], all the while being practised with lots of reading activities and exercises [S37, S39, S42 and S59]. Apart from these, excerpts from books / texts that are compulsory as homework could be read in class [S56] and students could make oral presentations summarizing them during class [S61]. Then, discussions on these could be conducted between groups or as a class [S18, S20, S14, S39 and S45].

On another note, participants of the study consider reading lessons as opportunities where students could improve their pronunciation, expressing views in this direction. For example, for candidate number S16, the purpose of these classes should be the improvement of pronunciation. To that end, reading texts should be increased [S55] and reading in class should be done aloud by different students [S62]. In case readers make pronunciation mistakes, teachers should correct them by making them repeat the correct version several times [S02, S38, S49, S53 and S60], because the more reading will be done, the more the skill in question will improve [S03]. After candidate number S07, reading in class should be done by the teacher instead of the student, for the teacher is a correct role model to be followed by students. Additionally, reading competitions [S63] could be organized during class (i.e. to find out who reads the most words in a given period of time), or, translation activities could be carried out on texts [S33].

\section{Opinions on this skill's relationship with other linguistic skills and objectives}

In this category, teacher candidates express that the other fundamental linguistic skills, namely, "writing" (f=4), "listening-comprehension" ( $\mathrm{f}=3$ )", and "speaking" ( $\mathrm{f}=2$ ), are part of the teaching process of the reading skill, as well as linguistic objectives such as "phonetics" ( $\mathrm{f}=6)$, "vocabulary" ( $\mathrm{f}=4)$ and "grammar" ( $\mathrm{f}=1)$. They even state that these factors not only are part of the teaching process, but that they go as far as influencing it directly or indirectly.

The results of the analysis show that students primarily associate the teaching of the reading skill with the writing skill: They state that this course could be carried out with the writing course [S54] or in parallel with it [S09] because, according to them, the texts they create during the writing course could be analyzed through questions during this lesson. Furthermore, they also mention that the reading courses direct [S30] or indirect [S52] contribution to the development of the writing skill is significant and cannot be ignored. On another note, they affirm that aloud reading activities are influencing the speaking skill [S02], and that the oral summary by students of stories treated during class [S61] could contribute to their speaking skill. Lastly, they declare the reading class should be held after the listening-comprehension class [S24], for good reading stems from sufficient listening [S27], and if exams could be done by making students listen to small excerpts [S52], this skill could very well contribute to the listening skill too.

As far as the reading skill's relationship with linguistic objectives, teacher candidates emphasize that concentrating on students' pronunciation in class by making them read long paragraphs aloud [S49], conducting this course in parallel with the phonetics course [S08], making students read the passages aloud so to work on their pronunciation [S23], instilling students with a sound knowledge of phonetics to ensure a solid development of the reading skill [S27] and the consolidation of pronunciation through reading texts [S24] are essential. Thus, participants actually express that the reading skill is primarily dependent on phonetics. In addition, some argue that correct pronunciation and the development of vocabulary should be the main aims of this course [S16], that reading is also crucial for the set of vocabulary [S37] and the teaching of it [S23]. They also add that it directly influences the teaching of grammar [S37] and that vocabulary that deepens with each text read allows students greater freedom of expression when speaking and writing [E41]. 


\section{Opinions on what should also be done outside of class}

Among participants of the survey, 15 teacher candidates have expressed opinions on what to do outside of class with respect to the reading skill. Accordingly, most of them believe that, in order to improve their reading skill, students learning French should, first of all, read a great number of books [S43]. In order to do so, at the very beginning, students should be instilled with the habit of reading outside of class as well and they must be introduced to the pleasure of reading [S58]. To make them adopt that habit, short texts could be assigned on a weekly basis [S28] or, starting with short stories, at least one book in French (novel or story) could be determined each week [S11, S22 and S61]. Afterwards, short summaries of these can be requested by the teacher as assignments [S36 and S52].

In addition, reading sessions could be organized outside of classes [S02 and S53]. Students could be informed about reading techniques [S02] and encouraged to read at least one paragraph every day [S08]. Moreover, students could read aloud either on their own or in the company of their fellows [S63], and they could be asked to make research on the content of the texts that have been selected for that activity [S18].

\section{Opinions on the nature of the reading skill}

Even though their number is low, some teacher candidates $(\mathrm{f}=5$ ) have defined the reading skill under this category, explaining its role and importance in the teaching of foreign language and expressing some of their perceptions and opinions on this skill. So much so that, according to one of the participants of the survey [S04], the reading skill is a vital linguistic skill that should be practised willingfully by the student. Moreover, this skill is key in seeing what is treated in texts in foreign language, how it is treated and with which patterns. As for another candidate [S07], the reading skill is more easily adopted than the speaking skill for when there is a text in front of the student, what they will say next is already given and thus, they do not feel any anxiety. Not to mention that, for other candidates, since this skill requires autonomous practising [S50], it is actually the easiest skill to be adopted when learning a foreign language [S02]. Nevertheless, for one candidate [S35] reading skills is a tough course to attend, and the reason for this would be that French has its idiosyncratic reading rules which make it difficult to understand what is being read.

Before proceeding to the discussion, findings collected from the analysis of the study's data are summarized in the table below (Table 2).

Table 2: Summary of the study's findings

\section{What should be read during class? [45 candidates]}

Articles, news, dialogues, caricatures, comics from daily newspapers; or of contemporary novels and tales.

The language used in selected texts should match students' level

At first, simple and short stories (3 candidates); later on, novels, tales and poems should be read (4 candidates)

\section{How should the reading course be conducted? [34 candidates]}

Aloud reading in class and correction of students' pronunciation mistakes Use of the text examination and analysis method

Oral presentations of the texts' summaries in class and discussions to be held on these

Organization of reading activities

Ensuring that students actively participate to the course

Instillation of a reading infrastructure and strategy to students

Reading of text excerpts during class

\section{Opinions on this skill's relationship with other linguistic skills and objectives [20} candidates]

Linguistic objectives: Phonetics (6 candidates), vocabulary (4 candidates ) and grammar

(1 candidate)

Linguistic skills: Writing (3 candidates), listening-comprehension (3 candidates) and speaking

(2 candidates)

\section{Opinions on what should also be done outside of class [15 candidates]}

Stressing that students should read a lot of books

Instillation of reading outside of class (1 candidate): In order to make the student adopt this hab.

At least one book in French (novel or story) could be read each week

Short summaries could be made of books that have been read

Reading sessions could be organized outside of course hours

Short texts could be assigned on a weekly basis

Students could be informed about reading techniques

Students could be asked to read at least one paragraph each day

Students can read texts aloud either on their own or in the company of their fellows

Students can be asked to make research on the content of texts assigned to them
Candidate (f) 


\section{What kind of skill is the reading skill? [5 candidates]}

Candidate (f)

It is a very important linguistic skill that should be used by students willingfully

It is a skill that is more easy to adopt compared to the speaking skill

\section{Discussion and Conclusion}

In this section, the findings of the study will be compared with existing findings in literature and will be discussed, as they respectively appear in the findings sections.

When we observe the opinions and suggestions of teacher candidates on the type of texts that should be read in class when teaching the reading skill, we can determine that instead of literary texts, authentic contents / documents that could match students' language and comprehension levels and grab their attention such as contemporary articles, caricatures, news etc. from French newspapers and magazines should be preferred. Moreover, candidates stress that long and boring texts should not be treated in class. Similarly, Rodríguez Pedreira (2013) claim that national and international presses are a good tool and resource for teachers to wield for students to keep up with political, economic, cultural and social headlines. Nowadays, Internet is an easier tool for reaching such sources, especially for students. However, Emaish (2007) and Carras et al. (2007) express that the teacher should have an active role in the selection and application of activities and choose texts and documents that match students' level, that grab their attention, that are adaptable, all the while taking into account linguistic objectives to be instilled to them.

Furthermore, teacher candidates express that first simple French stories, then contemporary novels, and lastly tales and poems should be assigned to students in order to consolidate the reading skill along their progress. The findings on the use of literary texts in the teaching of a foreign language also coincide with Ouhibi-Ghassoul (2003) and AllamIddou (2015)'s views. In other words, according to Ouhibi-Ghassoul (2003), literary texts are more functional and "elaborated" in terms of linguistics compared to all other texts, and thus, they are suitable for the teaching of French. Once more, after Allam-Iddou (2015), literary texts are the ideal educational tools, for they allow the student to acquaint with another's language and the culture of that language, to immerse themselves in it, and to construct their own authentic identity based on it thanks to the interaction students get to have with these types of texts.

Even though participants of the study have expressed a great number of opinions and suggestions on the way the course should be conducted, most have emphasized that the student should be encourage to read aloud in class in order to have their pronunciation corrected. For Lah (2013), although reading aloud in class is never really in vogue in the teaching of a foreign language, it is everyone's mutual agreement that this practice is an efficient activity in today's foreign classes and that it could be used to reinforce the Common European Framework of Reference for Languages' (2001) "orthoepic" competence, the skill which allows to make correct pronunciation out of written narration. Moreover, Trocme-Fabre (1987) declare that reading aloud is a rich cerebral activity that stimulates a total of 14 cerebral points in the brain, with 7 in each lobe.

On another note, candidates foresee respectively the following with regards reading skill courses is: the use of the text examination and analysis method when treating texts; the oral presentation of the texts' summaries in class and the engaging of a discussion on these; and lastly, the organization of different activities on texts read. Parallelly, with the use of the communicative approach in the teaching of French as a foreign language, Lehmann and Moirand (1980) suggest the "holistic (global) approach" they have formulated as text examination and analysis method for reading classes. With this approach that is also defined as a "learning strategy" by its creators, students examine what they read via indirect practices -such as the search for iconic, discursive, morphological, thematic and enunciative symbols- and get a holistic (global) idea of the text, instead of decyphering it word-by-word. This kind of approach is not solely a reading technique or strategy but also accelerates the student's decision-making process of whether or not they should deepen their reading of a certain text or not.

Participants suggest the oral summary and presentation of texts in class, followed by a discussion. This implies that the speaking skill is also to be included in the teaching of the reading skill. After mentioning in the past that, in the history of the teaching of French as a foreign language, the relationship / bond of these two intertwined skills have been widely treated, Boyer, Butzbach-Rivera and Pendanx (1990) determine that, in consequence, none is more primordial than the other, that there is no conflict / antagonysm between the two and that in fact, they may at times complement each other and can very well be taught simultaneously.

Lastly, teacher candidates suggest the carrying out of various reading techniques based on the documents that have been read during class, so that the essence of these can be better understood. Bertocchini and Costanzo (2008) as well foresee a rich three-stage series of activities to be realised for texts to be treated during the reading course: a) prereading stage: contextualisation and prominence activities; b) reading stage: finding of elements relating to the enunciative situation (who writes the text to whom, where, when and why), determination of the text's typology, finding of certain specific elements in the text, filling in the blanks, re-structuration of passages that have been shuffled 
and c) post-reading stage: various types of questions on the text (closed / open-ended questions, multiple-choice questions, true / false questions), recreation of a new text by altering the text's typology, guessing the end which has been deleted, preparation of a small survey where students' opinions on the text will be expressed, drawing of a picture or description of one or more of the protagonists, places, objects in the text, and lastly, transformation of the same text into an oral discourse without changing its content (for example, dramatization of a piece of news in the paper, turning an e-mail exchange into a telephone call, etc.) In addition to these activities, Cuq and Gruca (2008) propose puzzles, association, synthesis, analysis and comparison as similar activities.

As regards findings on the association of the reading skill with other linguistic skills and objectives, as has been mentioned above, participants see reading lessons as the best opportunity to correct their pronunciation. Indeed, at this stage, among linguistic objectives, candidates associate the reading skill with pronunciation the most. Then, they associate it with vocabulary and grammar, since they believe that texts / documents will contribute to their set of vocabulary and their grammatical level. The same is true for other fundamental linguistic skills. As a main linguistic skill, the reading skill is intertwined with other linguistic skills and they all present a global entity. Briefly, a linguistic skill cannot be ignored while teaching or consolidating another skill. As a matter of fact, through the texts and exercises prepared by Barth and Chovelon (2010) in their course book Le Français par les textes 2 (French through texts II) targeting the B1 and B2 levels of French for the reading skill in the Common European Framework of Reference for Languages (2001), the enrichment and consolidation of students' grammatical and vocabulary knowledge has been primarily set as purpose. Right after, various activities on the writing and speaking skills have been foreseen in order to allow students to easily express their personal opinions on the subjects that have been treated in the texts.

As is the case in the teaching of the mother tongue, when learning a foreign language, students need to be supported in a multi-dimensional fashion during reading courses so that they may become autonomous and eager lifelong-learners with a proficient reading level. Indeed, teacher candidates who participated in the study have suggested many concrete solutions for the improvement of the reading skill, from the frequent reading of French works at first to the use of different reading techniques. These suggestions also reveal the level of consciousness teacher candidates have with respect to the development of their reading skill.

The study's findings on the nature of the reading skill among other linguistic skills have shown that it has a direct correlation to foreign language proficiency levels and to the eagerness to read. In other words, for individuals whose foreign language proficiency level is high and who are eager to read, the reading skill is easy to adopt; however, for those of those do not have a high level of foreign language proficiency and who are not that eager to read, the reading skill becomes a hardship.

Consequently, we see that students' opinions and suggestions do match with findings, approaches and methods suggested in literature. This demonstrates that, as regards their field of study (Teaching of French Language Programme), students have a great number of theoretical, scientific (linguistic), methodological and didactical knowledge and achievement. On the other hand, as teacher candidates who participated in the present study have strongly and clearly stated, it is crucial and inevitable to develop and apply language learning strategies that will allow teacher candidates to not only learn to read more easily, but to transfer other linguistic skills and areas by ensuring the durability of their acquisitions.

\section{Acknowledgements}

We would like to express our gratitude to students enrolled at Uludag University Faculty of Education French Teaching Programme during the fall semester of the 2011-2012 academic year who had the kindness to participate in the present study and to answer our questions.

\section{References}

Achard-Bayle, G. (1984). Lecture en français langue étrangère [Reading in French as a foreign language]. Les Langues Modernes: lecture et compréhension écrite, 77(6), 499-508.

Adam, J.-M. (1997). Les textes: types et prototypes. Récit, description, argumentation, explication et dialogue [Texts: types and prototypes. Narrative, description, argumentation, explanation and dialogue]. Paris: Armand Colin.

Akyol, H. (2006). Turkce ilkokuma yazma ogretimi [Turkish literacy teaching]. Ankara: PegemA.

Allam-Iddou, S. (2015). De l'usage des textes littéraires comme outil didactique pour l'enseignement/apprentissage du Français Langue Étrangère [About the use of literary texts as didactic tool for teaching / learning of foreign language French]. Synergies Chili, 11, 95-103.

Barth, M., \& Chovelon, P. (2010). Le Français par les textes II [French through texts II]. Grenoble: Presse universitaire de Grenoble.

Basturk, S. (2011). Matematik ogretmen adaylarinin egitim fakultesindeki egitim-ogretim surecini degerlendirmeleri [Mathematics teacher candidates' evaluations of teaching and learning process in faculty of education]. International Journal of Human Sciences, 8(1), 58-94. 
Beacco, J. C. (1991). Types ou genres? Catégorisations des textes et didactique de la compréhension et de la production écrite [Types or types? Categorization of texts and didactics of understanding and written production]. Études de linguistique appliquée, 83, 19-28.

Benito, M. J. A. (2003). La lecture et le document authentique en classe de FLE [Reading and authentic document in FFL class]. In I. I. Las Heras \& M. J. S. Cascante (Eds.), El texto como encrucijada: estudios franceses y francófonos (Vol.2) (pp.607-616). Espagne: Universidad de La Rioja.

Bertocchini, P., \& Costanzo, E. (1989). Manuel d'autoformation: à l'usage des professeurs de langues [Self-study manual: for language teachers]. Paris: Hachette.

Bertocchini, P., \& Costanzo, E. (2008). Manuel de formation pratique pour le professeur de FLE [Practical training manual for the FFL teacher]. Paris: Clé International.

Besse, H. (1984). Sur quelques aspects culturels et métalinguistiques de la compréhension d'un document en classe de langue [On some cultural and metalinguistic aspects of the comprehension of a document in a language class]. Tranel, 6,135-145.

Besse, H. (1985). Méthodes et pratiques des manuels de langue [Methods and practices of language manuals]. Paris: Didier-Crédif.

Boubir, N. (2010). Les stratégies de compréhension utilisées lors de la lecture de textes en FLE chez des étudiants algériens [The comprehension strategies used when reading texts in FFL among Algerian students]. Synergies Algérie, 9, 179-188.

Boucher, E. (2002). Lecture de textes à des fins académiques en L2 [Reading texts for academic purposes in L2]. La Revue de l'association québécoise des enseignants de français langue seconde, 23(1), 58-67.

Boyer, H., Butzbach-Rivera, M., \& Pendanx, M. (1990). Nouvelle introduction à la didactique du français langue étrangère [New introduction to didactics of French as a foreign language]. Paris: Clé international.

Brew, L. S. (2008). The role of student feedback in evaluating and revising a blended learning course. The Internet and Higher Education, 11(2), 98-105.

Buyukozturk, S., Cakmak, E. K., Akgun, O. E., Karadeniz, S., \& Demirel, F. (2014). Bilimsel arastirma yontemleri [Scientific research methodologies]. Ankara: PegemA.

Cameron, L. (2005). Teaching languages to young learners. UK: Cambridge University Press.

Carras, C., Kohler, P., Sjilagyi, E., \& Tolas, J. (2007). Le Français sur objectifs spécifiques et la classe de langue [French on specific objectives and the language class]. Paris: Clé International.

Cicurel, F. (1991). Lectures interactives en langue étrangère [Interactive readings in a foreign language]. Paris: Hachette.

Conseil de l'Europe. (2001). Un cadre européen commun de référence pour les langues: apprendre, enseigner, évaluer [A common european framework of reference for languages: learning, teaching, assessment]. Strasbourg: Division de politiques linguistiques.

Coskun, O. (2017). Yabanci dil ogretiminde eylem odakli yaklasim [The action-oriented approach to foreign language teaching]. Journal of Language and Literature Studies, 16, 83-101.

Coste, D. (1978). Lecture et compétence de communication [Reading and communication skill]. Le Français dans le Monde, 141, 25-34.

Cuq, J.-P., \& Gruca, I. (2008). Cours de didactique du Français langue étrangère et seconde [Didactics course of French as a second and second language]. Genoble: Presses universitaires de Grenoble.

Deschênes, A.-J. (1991). Les stratégies de lecture [Reading strategies]. In Les entretiens Nathan: Lecture (Acte 1) [The Nathan Interviews: Reading (Act 1)](pp.29-45). Paris: Nathan.

Dévelotte, C. (1990). Lire: un contrat de confiance [Read: a contract of trust]. Le Français dans le Monde, 253, 50-54.

Durmuscelebi, M. (2013). Anadilde okuma becerilerinin ikinci dilde okumaya etkilerinin incelenmesi [An investigation of the effects of reading skills in native language on foreign language reading. The Journal of Academic Social Science Studies, 6, 23-33.

Emaish, N (2007). La presse écrite: pour un enseignement communicatif-culturel du FLE [The print media: for a communicative-cultural education of FFL]. Dirasat: Human and Social Sciences, 34(3), 697-703. 
Eriskon-Cangil, B. (2008). Okumayi ogretmek: Almanca ogretmen adayi genclerin okuma ve kutuphane kullanma aliskanliklari [Teaching reading: Reading and library habits of young German teacher candidates]. In N. Kuruyazici (Ed.), Gencligin izdusumu-Nilufer Tapan Armagan Kitabi [Projection of youth-Book dedicated to Nilufer Tapan] (pp. 293-313). Istanbul: Multilingual Yabanci Dil Yayinlari.

Galisson, R. (1980). D’hier à aujourd'hui la didactique générale des langues étrangères [From yesterday to today the general didactics of foreign languages]. Paris: Clé International.

Gaonac'h, D. (1990). Lire dans une LE: approche cognitive [Reading in an FL: cognitive approach]. Revue Française de Pédagogie, 93, 75-100.

Gaonac'h, D. (2000). La lecture en langue étrangère: un tour d'horizon d'une problématique de psychologie cognitive [Reading in a foreign language: an overview of a problem in cognitive psychology]. Aile, 13, 5-15.

Gocer, A. (2007). Bir ogrenme alani olarak anlama egitimi ve Turkce ogretimindeki yeri [As a learning field the comprehension training and the stuation in Turkish teaching]. Erciyes University Journal of the Institute of Social Sciences, 23(2), 17-39.

González Hernández, A.-T. (2012). Paramètres pour la compréhension d'un texte écrit en langue étrangère [Parameters for understanding a written text in a foreign language]. La Clé des Langues. Retrieved June 15 2018, from http://cle.ens-lyon.fr/espagnol/parametres-pour-la-comprehension-d-un-texteecrit-en-langue-etrangere164559.kjsp.

Goodman, K. (1967). Reading: A psycholinguistic guessing game. Journal of the Reading Specialist, 6, 126-135.

Gunday, R. (2010). Démarche de lecture en classe de français langue étrangère [Reading procedure in French as a foreign language class]. Synergies Turquie, 3,191-204.

Kartal, E. (1999). Analyse des textes utilisés dans les méthodes actuelles de l'enseignement du français langue étrangère [Analysis of texts used in current methods of teaching French as a foreign language] (Mémoire de maîtrise nonpunlié). Université Hacettepe, Institut des Sciences Sociales, Ankara, Turquie.

Kartal, E., \& Melek, A. (2017). Fransizca dinleme becerisi ogretimine dair ogretmen adaylarinin gorus ve onerileri: Uludag Universitesi ornegi [Pre-service teachers' views and recommendations about the teaching of French speaking skill: The case of Uludag university]. $2^{\text {nd }}$ International Conference on Best Practices and Innovations in Education, 19-21 October 2017, Izmir, Turkey.

Kartal, E., \& Melek, A. (2017). Fransizca konusma becerisi ogretimine dair ogretmen adaylarinin gorus ve onerileri: Uludag Universitesi ornegi [Opinions and suggestions of prospective teachers on the teaching of listening skills in French: The case of Uludag University]. $2^{\text {nd }}$ International Conference on Best Practices and Innovations in Education, 19-21 October 2017, Izmir, Turkey.

Kartal, E., \& Parlak, E. (2016). Optique des apprenants du Français langue étrangère au regard de l'évaluation [Optics of learners of French as a foreign language in terms of evaluation]. 9e Congrès Panhellénique et International des Professeurs de Français: Enseigner la langue et la culture françaises: Construire des ponts socio-humanistes, du 20 au 23 Octobre 2016, Athènes, Grèce.

Kartal, E., \& Parlak, E. (2016). Perspectives des apprenants de FLE à l'égard de l'expression écrite [FFL learners' perspectives on written expression]. XIVe Congrès mondial Fédération Internationale des Professeurs de Français: Français, langue ardente, du 14 au 21 Juillet 2016, Liège, Belgique.

Kartal, E., \& Parlak, E. (2017). Etkin bir Fransizca ogretimi icin ogretmen adaylarinin gorus ve onerileri: Uludag Universitesi ornegi. [Opinions and suggestions of prospective teachers for an effective French teaching: The case of

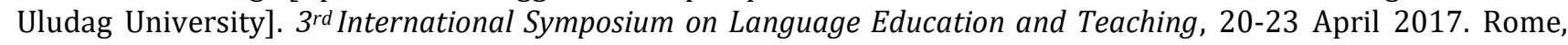
Italy.

Kunze, D. L. (2012). La Lecture interactive et la compréhension de textes en classe de Français langue étrangère [Interactive reading and comprehension of texts in French as a foreign language class]. Pensar línguas estrangeiras (PLE), 1(1), 1-16.

Lah, M. (2013). La lecture à haute voix en classe de langue étrangère: une activité à réhabiliter? [Reading aloud in a foreign language class: an activity to rehabilitate?] Linguistica, 53(1), 199-207.

Lavaur, J. M. (1995). Le traitement cognitif des textes en LE [Cognitive processing of texts in FL]. Les langues Modernes, 2, 25-33.

Lee, J.-W., \& Schallert, D. L. (1997). The relative contribution of L2 language proficiency and L1 reading ability to L2 reading performance: A test of the threshold hypothesis in an EFL context. Tesol Quarterly, 31(4), 713-739. 
Lehmann, D. \& Moirand, S. (1980). Une approche communicative de la lecture [A communicative approach to reading]. Le Français dans le Monde (Recherches et Applications), 153, 72-79.

López Alonso, C., \& Seré de Olmos, A. (1996). Typologie des textes et stratégies de la compréhension en LE [Typology of texts and strategies of understanding in FL]. Études de Linguistique Appliquée, 104, 441-450.

Miles, M. B., \& Huberman, M. A. (1994). An expanded sourcebook qualitative data analysis. (2 ${ }^{\text {nd }}$ ed.). California: Sage Publications.

Moirand S. (1979). Situations d'écrit: compréhension, production en langue étrangère [Typology of texts and strategies of understanding in FL]. Paris: Edition Hachette.

Odabas, H., Odabas, Z. Y., \& Polat, C. (2008). Univeriste ogrencilerinin okuma aliskanligi: Ankara Universitesi ornegi [Reading habit of university students: The model of Ankara University]. Information World, 9(2), 431-465.

Oppenheim, A.N. (1992). Questionnaire design, interviewing and attitude measurement. London: Pinter Publishers Ltd.

Ouhibi-Ghassoul, N (2003). Le savoir-savant: introduction du texte littéraire en cours de langue étrangère [Know-how: Introduction of literary text into a foreign language course]. Interculturalité et Didactique, 7, 109-115.

Pallotti, G. (2002). La classe dans une perspective écologique de l'acquisition [Class in an ecological perspective of the acquisition]. Acquisition et interaction en langue étrangère, 16, 165-197.

Pekkanli, I., \& Kartal, E. (2010). Yabanci dil ogretmen adaylarinin anadil ve yabanci dilde okuma aliskanliklari uzerine bir arastirma: Uludag Universitesi Egitim Fakultesi ornegi [A research on the native and foreign language reading habits of the foreign language teacher candidates: Case of Uludag University Faculty of Education] Zeitschrift fur die Welt der Turken, 2(3), 91-105.

Piji Kucuk, D. (2014). Muzik ogretmeni adaylarinin bakisi ile eslik calma dersinin degerlendirilmesi [Evaluation of accompaniment playing course with the perspective of pre-service music teachers]. Hacettepe University Journal of Education, 29(2), 198-214.

Rodríguez Pedreira, N. (2013). Le document de presse dans un cours de FLE/FOS: de la théorie à la pratique de classe [Press release in a FFL / FSO course: From theory to classroom practice]. Thélème: Revista Complutense de Estudios Franceses, 28, 221-242.

Rui, B. (2000). Exploration de la notion de "stratégie de lecture" en français langues étrangère et maternelle [Exploring the notion of "reading strategy" in French as a foreign language and mother tongue]. Acquisition et interaction en langue étrangère, 13, 89-110.

Souchon, M. (2000). Lecture de textes en LE et compétence textuelle [Reading of texts in FL and textual competence]. Acquisition et interaction en langue étrangère, 13, 15-40.

Tagliante, C. (1994). La classe de langue [The language class]. Paris: Clé International.

Trocme-Fabre, H. (1987). J'apprends, donc je suis: introduction à la neuropédagogie [I am learning, so I am: Introduction to neuropedagogy]. Paris: Editions d'Organisation.

Van Chuong, V. (2003). Procédés anaphoriques et lecture en FLE [Anaphoric processes and reading in FFL]. Le Français dans le Monde, 327, 29-30.

Vigner, G. (1979). Lire: du texte au sens: éléments pour un apprentissage et un enseignement de la lecture [Reading: from text to meaning: elements for learning and teaching reading]. Paris: Clé International.

Vigner, G. (1996). Lire: comprendre ou decoder? [Reading: understanding or decoding?] Le Français dans le Monde, $283,62-69$.

Weiss, F. (1979). Expression et prise en compte des besoins langagiers [Expression and taking into account of language needs]. Le Français dans le Monde, 149, 59-62.

Wlassoff-Delahousse, M. (1997). Approche globale et typologie des textes [Global approach and typology of texts]. Le Français dans le Monde, 291, 60-65.

Yildirim, A., \& Simsek, H. (2011). Sosyal bilimlerde nitel arastirma yontemleri [Qualitative research methods in the social sciences] (8 ${ }^{\text {th }}$ Edition). Ankara: Seckin Yayinevi. 